DOI: $10.20472 /$ IAC.2018.044.010

\title{
SALOUA CHAOUCHE
}

École nationale supérieure de statistique et d'économie appliquée, Algeria

\author{
RACHID TOUMACHE \\ ENSSEA d'Alger, Algeria
}

IMANE BENAMEUR

ENSSEA, Algeria

\section{NATURAL RESOURCES FROM CURSE TO A BLESSING : CONJURING THE CURSE}

\begin{abstract}
:
Many countries are blessed with natural resources which logically have the power to transform their economies, so that the development of the natural resource could produce wealth for that nation, but actually it leads to become overly dependent on one resource, to the detriment of the rest of the economy.

In fact, the discovery of natural resources is very often followed by economic instability in many of those countries. Moreover, the volatile resource prices have especially negative impacts on weak-state economies and cause growth to be unstable, so the resource-rich countries often do not pursue sustainable growth strategies. They fail to recognize that if they do not reinvest their resource wealth into productive investments above ground, they are actually becoming poorer.

Given this very sad picture, one can ask if the curse of natural resources is a fatality, can anything be done? The main point for our purpose is to explore if the improvement of the governance, education sector, and high institutional quality with more transparency can be the antidotes and will help to conjure the spell and turn to "resource blessing".

Using the $L S$ method we estimated the regression whose dependent on GDP variable for the period from 1986 to 2017, which is a function of a vector of explanatory variables, including the variable that measures the abundance of natural resources, those measuring institutional quality, as well as other control variables.

We chose two ways to measure the abundance of natural resources to ensure that our results are unbiased: The first measure is the percentage of oil, gas and ores rent from GDP. The second measure is the logarithm of one plus the value of per capita oil production.

We used as measure of institutional quality : Rule of law that represents the credibility rate of the population in state institutions, regulatory quality which reflects the ability of the public authorities to put in place sound policies and regulations that allow the development of the private sector. Government Effectiveness which reflects the perception of the quality of public services, the quality of the public service and its degree of independence from political pressures, the quality of policy formulation and implementation, and credibility of the government's commitment to these policies. And we used: degree of openness, gross fixed capital formation, life expectancy at birth, and number average years of schooling at the age of 15 as control variables.
\end{abstract}

\section{Keywords:}

Natural resources, institution quality, government effectiveness 
JEL Classification: C19, C59, C51 